В.В. Красинский,

доктор юридических наук

\title{
Международно-правовые основы противодействия партийной и электоральной коррупции на пространстве Содружества Независимых Государств
}

Красинский B.B. Международно-правовые основы противодействия партийной и электоральной коррупции на пространстве СНГ // Право и образование. 2012. № 7; www.krasinskiy.ru

Политические процессы, происходящие на пространстве Содружества Независимых Государств (рост числа злоупотреблений и превышения должностных полномочий, взяточничество государственных служащих и лиц, занимающих государственные должности, фальсификации избирательных документов, массовый подкуп избирателей, продажа мест в партийных списках, нецелевое расходование бюджетных средств, злоупотребления при формировании и расходовании средств избирательных фондов и др.), свидетельствуют о том, что, несмотря на национальные планы и концепции борьбы с коррупцией, коррупция глубоко проникла в политическую сферу, поразила банковский сектор, партийные структуры, органы государственной власти и местного самоуправления.

C учетом возросших масштабов коррупционной пораженности, повышенной общественной опасности коррупционных правонарушений, значимости антикоррупционной политики, противодействие партийной и электоральной коррупции в государствах Содружества в XXI веке стало осуществляться не только на национальном, но и на международном уровне. Правосубъектность государств-участников СНГ в сфере противодействия партийной и электоральной коррупции определяется не только их национальными законами, но и форматом участия в международных организациях и наличием соответствующих политико-правовых обязательств ${ }^{1}$.

Bce 11 государств-участников СНГ (Азербайджанская Республика, Кыргызская Республика, Республика Армения, Республика Беларусь, Республика Казахстан, Республика Молдова, Республика Таджикистан, Республика Узбекистан, Российская Федерация, Туркменистан, Украина) являются членами $\mathrm{OOH}$ и ОБСЕ, 6 государств Содружества являются членами ГРЕКО (ГруппЫ государств против коррупции) (Республика Армения, Азербайджанская Республика, Республика Беларусь, Республика Молдова, Российская Федерация и Украина), 5 государств (Азербайджанская Республика, Республика Армения, Республика Молдова, Российская Федерация, Украина) - члены Совета Европы, 5 (Республика Казахстан,

1 Законы о борьбе с коррупцией приняты в Украине, Республике Беларусь, Азербайджанской Республике, Республике Казахстан, Республике Молдова, Республике Таджикистан, Кыргызской Республике, Российской Федерации. 
Кыргызская Республика, Российская Федерация, Республика Таджикистан, Республика Узбекистан) - члены ШОС.

Первостепенное значение в структуре международно-правовых основ противодействия партийной и электоральной коррупции имеют универсальные акты $\mathrm{OOH}^{1}$.

Антикоррупционные стандарты ООН закреплены в Кодексе поведения должностных лиц по поддержанию правопорядка (принят резолюцией ГА $\mathrm{OOH} \mathrm{34/169} \mathrm{от} 17$ декабря 1979 года), Международном кодексе поведения государственных должностных лиц (Приложение к Резолюции ГА ООН № 51/59 «Борьба с коррупцией» от 12 декабря 1996 года), Конвенции ООН против транснациональной организованной преступности (г. Палермо, 15 декабря 2000 года) и Конвенции ООН против коррупции (58 сессия ГА ООН, 21 ноября 2003 года).

В Кодексе поведения должностных лиц по поддержанию правопорядка отмечалось, что должностные лица по поддержанию правопорядка не совершают акты коррупции. На должностных лиц возлагалась обязанность всемерно препятствовать любым таким актам и бороться с ними.

В Международном кодексе поведения государственных должностных лиц сформулировано определение государственной должности, общие принципы осуществления официальных функций государственными должностными лицами, положение о недопустимости коллизии между обязанностями и частными интересами государственных должностных лиц, закреплены требования о сообщении государственными должностными лицами сведений о личных активах и обязательствах, а также об активах и обязательствах супруга (супруги) и иждивенцев. В разделе VI Международного кодекса установлено, что государственные должностные лица участвуют в политической деятельности вне рамок их официальных обязанностей в соответствии с законами и административными положениями таким образом, чтобы не подрывать веру общественности в беспристрастное выполнение ими своих функций и обязанностей.

В ст. 8 Конвенции ООН против транснациональной организованной преступности дан перечень уголовно-наказуемых форм коррупции, а в ст. 9 указаны меры выявления и предупреждения коррупции среди публичных должностных лиц и наказания за нее 2 .

Важнейшим международным документом в сфере противодействия партийной и электоральной коррупции является Конвенция ООН против

1 Предметом настоящей статьи является рассмотрение международных актов, регулирующих противодействие партийной и электоральной коррупции, территориальное действие которых распространяется на пространство СНГ.

2 Ратифицирована Федеральным законом от 26 апреля 2004 года № 26-Ф3 «О ратификации Конвенции ООН против транснациональной организованной преступности и дополняющих еe Протокола против незаконного ввоза мигрантов по суше, морю и воздуху и Протокола о предупреждении и пресечении торговли людьми, особенно женщинами и детьми, и наказании за нее». 
коррупции ${ }^{1}$. В преамбуле Конвенции отмечается, что порождаемые коррупцией угрозы подрывают демократические институты, наносят ущерб политической стабильности и устойчивому развитию государств. В статье 7 данного документа закреплена возможность государств устанавливать критерии применительно к кандидатам и выборам на публичные должности, принимать законодательные и административные меры, чтобы усилить прозрачность в финансировании кандидатур на избираемые публичные должности и финансировании политических партий. В соответствии со ст. 63 Конвенции была учреждена Конференция государств - участников Конвенции. Каждое государство-участник обязалось представлять информацию о программах, планах и практике, а также о законодательных и административных мерах борьбы с коррупцией.

На региональном уровне существенный вклад в противодействие партийной и электоральной коррупции вносит Совет Европы.

8 ноября 1990 года в Страсбурге была подписана Конвенция Совета Европы об отмывании, выявлении, изъятии и конфискации доходов от преступной деятельности (ETS N 141). Договаривающиеся Стороны обязались криминализировать отмывание доходов от преступной деятельности, а также конфисковывать орудия и доходы от преступной деятельности.

Основополагающим документом, заложившим фундамент общеевропейского регулирования борьбы с коррупцией стала Резолюция Комитета Министров Совета Европы от 6 ноября 1997 года (1997) 24 «О двадцати Руководящих принципах борьбы с коррупцией» ${ }^{2}$. Руководящие принципы предполагали реализацию системы антикоррупционных мер, среди которых: разработка профилактических мер для предотвращения коррупции; криминализация национальной и международной коррупции; установление ответственности публичных должностных лиц за коррупционные деяния; обеспечение мер конфискации и лишения доходов от коррупции; ограничение иммунитетов от предварительного расследования и судебного преследования по делам о коррупции; проведение антикоррупционных расследований; принятие кодексов поведения выборных должностных лиц и антикоррупционных правил при финансировании политических партий и избирательных кампаний; специализация должностных лиц и органов, ответственных за борьбу с коррупцией; международное сотрудничество по борьбе с коррупцией.

Очередным шагом Совета Европы на пути борьбы с коррупцией явилась Резолюция Комитета Министров Совета Европы от 1 мая 1999 года (1999) 5 «О создании ГРЕКО». С ее принятием был создан не только институциональный механизм мониторинга соблюдения Руководящих принципов борьбы с коррупцией, но и контроля за выполнением международных договоров в сфере борьбы с коррупцией.

1 Ратифицирована Федеральным законом от 8 марта 2006 года № 40-Ф3 «О ратификации Конвенции Организации Объединенных Наций против коррупции».

${ }^{2}$ URL: //http://www.coe.int/t/dghl/monitoring/greco/documents/Resolution(97)24_EN.pdf 
Ведущая роль Совета Европы в европейском антикоррупционном правотворчестве проявилась при разработке и принятии Конвенции Совета Европы об уголовной ответственности за коррупцию (Страсбург, 27 января 1999 года $)^{1}$ и Конвенции Совета Европы о гражданско-правовой ответственности за коррупцию (Страсбург, 4 ноября 1999 года) $)^{2}$ В этих международно-правовых договорах нашли отражение меры, принимаемые на национальном уровне, для установления уголовной и гражданско-правовой ответственности за коррупцию. Данные меры предполагают создание специализированных органов по борьбе с коррупцией, санкции физическим и юридическим лицам, меры защиты сотрудничающих с правосудием лиц и свидетелей, меры содействия сбору доказательств и конфискации доходов, возмещение ущерба от коррупции, сроки исковой давности по возмещению ущерба, отчеты и аудит, недействительность сделок, связанных с коррупциейํ․

Договорная база Совета Европы в сфере противодействия партийной и электоральной коррупции тесно связана с кодексами поведения местных и региональных выборных представителей, a также государственных служащих.

В развитие антикоррупционных положений Международного кодекса поведения государственных должностных лиц (Резолюция ГА ООН № 51/59 «Борьба с коррупцией» от 12 декабря 1996 года) Советом Европы 17 июня 1999 года и 11 мая 2000 года были приняты Европейский кодекс поведения для местных и региональных выборных представителей и Модельный кодекс поведения государственных служащих ${ }^{4}$.

Согласно статье 8 Европейского кодекса поведения для местных и региональных выборных представителей выборные представители не выполняют своих функций и не исполняют своих должностных прерогатив в частных интересах отдельных лиц или групп с целью извлечения прямой или косвенной личной выгоды. При выполнении своих функций выборные представители воздерживаются от поступков, которые согласно действующим нормам внутреннего или международного уголовного права можно квалифицировать как дача или получение взяток (ст. 13). Выборные представители при вступлении в должность тщательно соблюдают любые требования действующего законодательства в отношении обнародования источников и сумм доходов, которые были предназначены для

${ }^{1}$ Конвенции Совета Европы и Российской Федерации: Сб. док. М.: Юрид. лит., 2000. С. 281-289. Ратифицирована Федеральным законом от 25 июля 2006 года № 125-Ф3 «О ратификации Конвенции Совета Европы об уголовной ответственности за коррупцию».

${ }_{3}^{2}$ URL://http://conventions.coe.int/Treaty/Commun/QueVoulezVous.asp?CL=RUS\&NT=174

3 Как отмечают О.И. Тиунов, А.А. Каширкина и А.Н. Морозов, «ратификация Российской Федерацией антикоррупционных конвенций повлекла за собой совершенствование целого ряда законодательных актов Российской Федерации, относящихся к таким отраслям законодательства, как конституционное, уголовное, административное, финансовое, трудовое и т.д.». Тиунов О.И., Каширкина А.А, Морозов A.H. Влияние норм международного права на развитие национального законодательства // Журнал российского права. 2010. № 6.

${ }^{4}$ URL:// http://www.coe.int/t/dghl/monitoring/greco/documents/Rec(2000)10_EN.pdf 
финансирования избирательных кампаний, а также характера и сумм расходов. При отсутствии действующих правил на этот счет они предоставляют такую информацию по обычному запросу.

Модельный кодекс поведения государственных служащих Совета Европы имеет несколько отличий от Международного кодекса поведения государственных должностных лиц ООН. Во-первых, он распространяет свою юридическую силу на всех государственных служащих, кроме членов правительства, судей и депутатов законодательных органов власти. Вовторых, данный документ содержит более детальные правовые предписания, чем Кодекс ООН. В-третьих, соблюдение Модельного кодекса Совета Европы контролируется Группой государств против Коррупции (ГРЕКО).

В Модельном кодексе установлены антикоррупционные ограничения, обязанности и ответственность государственных служащих. Так, на госслужащих возложены обязанности сообщать о конфликте интересов, соблюдать ограничения на участие в политической и общественной деятельности, закреплены ограничения в отношении бывших госслужащих на принятие трудовых предложений и деятельность в интересах физических и юридических лиц, с которыми они были связаны на государственной службе, установлена ответственность вышестоящих руководителей подразделений за коррупционные действия (бездействие) подчиненных.

Среди актов Совета Европы, посвященных противодействию партийной и электоральной коррупции, видное место занимают Рекомендация ПАСЕ 1516 (2001) «О финансировании политических партий» и Руководящие принципы финансирования политических партий Венецианской комиссии (2001).

В Рекомендации ПАСЕ 1516 (2001) закреплены следующие правовые меры, направленные на предотвращение нарушений порядка финансирования избирательных кампаний и деятельности политических партий:

- запрет на пожертвования от государственных предприятий или организаций, оказывающих услуги в сфере государственного управления;

- запрет на пожертвования от организаций, зарегистрированных в оффшорах;

- жесткие ограничения на пожертвования от юридических лиц;

- ограничения максимального размера пожертвования;

- запрет на пожертвования от религиозных организаций.

Финансирование политических партий должно быть прозрачным, что требует от политической партии учета всех доходов и расходов, ежегодного представления финансовых отчетов, независимого аудита, а также идентификации спонсоров, которые оказывали партии финансовую поддержку, превышающую определенный размер. При нарушении установленного порядка финансирования политические партии должны подвергаться санкциям, в том числе полной или частичной потере государственного финансирования, обязательному возмещению государственных расходов, наказываться штрафами. В случае персональной 
ответственности санкции предполагают лишение избранного лица депутатского мандата или временную дисквалификацию. В Рекомендации 1516 (2001) также содержится предложение ПАСЕ государствам-членам принять законы о финансировании политических партий и избирательных кампаний ${ }^{1}$.

В соответствии с Руководящими принципами финансирования политических партий Венецианской комиссии (2001) (Страсбург, 9-10 марта 2001 г.) государственное финансирование должны получать все партии, представленные в парламенте. Государственное финансирование политических партий должно контролироваться специально уполномоченными государственными органами (например, Счетной палатой). В разделе «b» указаны возможные ограничения частного финансирования: максимальный размер пожертвования в избирательный фонд; запрет на прием пожертвований от промышленных предприятий, коммерческих и религиозных организаций; первостепенный контроль пожертвований членов партии, баллотирующихся на выборах. Каждая партия должна публиковать ежегодный финансовый отчет за предыдущий год, который должен содержать перечень всех пожертвований, кроме членских в3носов ${ }^{2}$.

В отличие от Рекомендации ПАСЕ 1516 (2001), Руководящие принципы финансирования политических партий Венецианской комиссии (2001) в качестве санкций за нарушения порядка финансирования избирательных кампаний и деятельности политических партий наряду с возможностью полной или частичной потери государственного финансирования на следующий год предусматривают отмену результатов выборов. В то же время в данном документе отсутствует прямое упоминание об обязательном возмещении государственных расходов на финансирование избирательной кампании.

Пункты «d» и «е» части 2 Раздела I Руководящих принципов Венецианской комиссии относительно выборов 2002 года акцентируют внимание на том, что «финансирование политических партий, кандидатов и избирательных кампаний должно быть транспарентным. Для обеспечения равенства возможностей могут быть ограничены расходы политических партий, особенно на агитацию»³.

Специализированным нормативным правовым актом в сфере противодействия партийной и электоральной коррупции стали принятые 8 апреля 2003 года Комитетом Министров Совета Европы Рекомендации «Об общих принципах борьбы с коррупцией при финансировании политических партий и избирательных кампаний».

1 URL: // http://assembly.coe.int/Mainf.asp?link=/Documents/AdoptedText/ta01/EREC1516.htm (дата обращения: 20 марта 2012 г.)

${ }^{2}$ URL: // http://www.venice.coe.int/docs/2001/CDL-INF(2001)008-e.pdf (дата обращения: 20 марта 2012 г.)

${ }_{3}$ Международные избирательные стандарты. Сб. документов // Отв. ред. доктор юрид. наук В.И. Лысенко. М.: ЦИК России, 2009. С. 428. 
В соответствии со статьей 9 указанных Рекомендаций государства должны предотвращать чрезмерные финансовые расходы политических партий и устанавливать общий размер расходов на ведение избирательной кампании. «Хотя юридическое обеспечение и должно разрешать избирающимся претендентам расходовать достаточные ресурсы, чтобы довести свои политические идеи до избирателей, нет никаких минимальных стандартов, которые предполагали бы возможность «купить» выборы» ${ }^{1}$.

Каждая политическая партия и каждый кандидат должны вести отдельную отчетность по всем расходам на избирательную кампанию. В отчетах политических партий должны быть сведения о всех пожертвованиях, полученных партией, включая вид и объем пожертвования (статьи 10 и 12 Рекомендации Rec (2003) 4 Комитета Министров Совета Европы) ${ }^{2}$. В этом документе отмечается, что государства должны требовать от кандидатов и политических партий представления и обнародования периодических отчетов по всем полученным пожертвованиям.

В статье 14 Рекомендации Rec (2003) 4 Комитета Министров Совета Европы закрепляется необходимость государства обеспечить независимый мониторинг финансирования политических партий и избирательных кампаний .

В целях борьбы с коррупцией в избирательном процессе статья 15 Рекомендации Rec (2003) 4 Комитета Министров Совета Европы содержит обязанность государств-участников Совета Европы осуществлять подготовку и «поддерживать специализацию судебного, милицейского и иного персонала на борьбе против незаконного финансирования политических партий и избирательных кампаний» ${ }^{3}$.

Следующим элементом структуры международно-правовых основ противодействия партийной и электоральной коррупции являются акты ОБСЕ.

Хартия европейской безопасности ОБСЕ (Стамбул, 19 ноября 1999 года) закрепила обязательства государств-участников вести борьбу с коррупцией во всех измерениях ОБСЕ, шире использовать существующие международные договоры, оказывать взаимную помощь в борьбе с коррупцией и взаимодействовать с неправительственными организациями, которые разделяют единодушное неприятие обществом и деловыми кругами коррупции.

В Бухарестской декларации Парламентской Ассамблеи ОБСЕ (Бухарест, 10 июля 2000 года) сформулировано требование принять законы, запрещающие тайное финансирование политических партий, компаний кандидатов или других политических организаций, санкционировать

${ }^{1}$ Международные избирательные стандарты. Сб. документов // Отв. ред.: кандидат юрид. наук А.А. Вешняков; науч. ред.: доктор юрид. наук В.И. Лысенко. М.: Издательство Весь Мир, 2004. С. 451.

2 Международные избирательные стандарты. Сб. документов // Отв. ред. доктор юрид. наук В.И. Лысенко. М.: ЦИК России, 2009. С. 382-383.

3 Международные избирательные стандарты. Сб. документов // Отв. ред. доктор юрид. наук В.И. Лысенко. М.: ЦИК России, 2009. С. 383. 
обнародование информации об источниках и объемах такого финансирования, а также установить правила и процедуры, необходимые для обеспечения и соблюдения транспарентности финансирования. В данной Декларации признается значимость антикоррупционного правотворчества Совета Европы и подчеркивается необходимость ратификации и применения международных актов Совета Европы по борьбе с коррупцией.

Государствам-участникам рекомендовано: создавать региональные инструменты поддержки и стимулирования регионального сотрудничества в вопросах противодействия коррупции; применять двадцать Руководящих принципов борьбы с коррупцией и Модельный кодекс поведения государственных служащих, принятые Советом Европы; ратифицировать или подписать Конвенцию Совета Европы об уголовной ответственности за коррупцию, Конвенцию Совета Европы о гражданско-правовой ответственности за коррупцию и присоединиться к Соглашению о создании организации «Группа государств против коррупции - ГРЕКО».

При подписании Парижской декларации Парламентской Ассамблеи ОБСЕ (Париж, 10 июля 2001 года) была принята Резолюция «О борьбе с коррупцией и международной преступностью в регионе ОБСЕ». Документ признает, что коррупция подрывает легитимность государственной власти и общественное доверие к ней. В Резолюции содержится призыв: к поощрению обнародования государственными официальными лицами, политическими партиями и кандидатами на выборные должности сведений о своем финансовом положении; к содействию в проведении свободных и честных общенациональных, региональных и местных выборов, предоставлению общественности доступа к информации о деятельности государственных учреждений, а также взаимодействию с институтами гражданского общества в борьбе с коррупцией; к принятию решительных мер для проведения в зонах конфликтов свободных и равноправных выборов при необходимом условии участия в выборах всего населения, проживавшего в этих местах до конфликта, как предпосылки для борьбы с коррупцией и организованной преступностью; к возможной ратификации и применению существующих международных соглашений по вопросам борьбы с коррупцией.

В части финансирования политических партий и избирательных кампаний необходимо обратить внимание на Рекомендации БДИПЧ/ОБСЕ по анализу законодательной базы выборов (Варшава, январь 2001 года) и Обязательства по проведению демократических выборов в государствахучастниках ОБСЕ (Варшава, 30 июня 2003 года).

В соответствии с Рекомендациями БДИПЧ/ОБСЕ государственное финансирование предоставляется политическим партиям и кандидатам на основе их равенства перед законом. Законодательство должно предотвратить возможные злоупотребления государственными ресурсами, выделенными для целей избирательной кампании, и гарантировать, чтобы эти ресурсы использовались в строгом соответствии с применимыми юридическими положениями... Эксперты ОБСЕ считают несовершенной законодательную базу, которая предусматривает исключительно государственное 
финансирование избирательной кампании. Любые запреты или ограничения частного финансирования могут являться нарушением права личности на свободу ассоциаций и свободу выражения.

Данное положение Рекомендаций, рассматривающее любые ограничения частного финансирования как ущемление прав личности, противоречит другой части Рекомендаций, в которой признается допустимость разумных ограничений размера частных пожертвований и общего размера расходов кандидатов. В соответствии с Рекомендациями БДИПЧ/ОБСЕ 2001 года законодательство должно требовать от кандидатов периодических отчетов, привязанных к разумным отрезкам времени, а также отчетов о всех полученных средствах и произведенных расходах. В качестве дополнительных гарантий транспарентности финансирования предлагается ввести законодательную возможность проверок отчетов кандидатов со стороны общественности, а также копирование избирателями отчетов кандидатов о полученных средствах и расходах на избирательную кампанию ${ }^{1}$.

В Обязательствах по проведению демократических выборов в государствах-участниках ОБСЕ 2003 года, в отличие от Рекомендаций БДИПЧ/ОБСЕ 2001 года позиция ОБСЕ об ограничениях частного финансирования смягчена. В пункте В раздела VII указано, что «государства могут устанавливать разумные ограничения на объемы частного финансирования политических партий и кандидатов, чтобы обеспечить честное соревнование в ходе выборов и понизить стимулы для коррупции и оказания излишнего влияния на политику». В Обязательствах расширен перечень недопустимых источников финансирования политических партий и кандидатов: «государства могут запрещать или ограничивать оказание финансовой или иной материальной и другой поддержки политическим партиям и кандидатам из определенных источников, таких, например, как иностранные граждане и организации, и должны предотвращать оказание непосредственной поддержки от государственных органов власти и государственных предприятий. Конкретный характер недопустимых источников и видов поддержки должен быть четко определен законодательством и, при необходимости, регламентирован компетентными органами государственной власти». В документе акцентируется внимание на необходимости периодического представления политическими партиями и кандидатами информации о финансовых средствах, полученных ими, их источниках, а также о расходах в ходе проведения избирательной кампании, и целях таких расходов. Обязанность контроля предоставления кандидатами информации о финансовых средствах и своевременной публикации данной информации предлагается возложить на Центральный орган, ответственный за организацию и проведение выборов, или другой официальный орган.

${ }^{1}$ Раздел X Рекомендаций БДИПЧ/ОБСЕ по анализу законодательной базы выборов / Международные избирательные стандарты. Сб. документов // Отв. ред. доктор юрид. наук В.И. Лысенко. М.: ЦИК России, 2009. С. 230-232. 
Самостоятельный блок международно-правовых основ противодействия партийной и электоральной коррупции в формате СНГ образуют акты Содружества.

В состав правовой базы государств-участников СНГ в сфере противодействия партийной и электоральной коррупции входят как нормативные договоры юридически обязывающего характера, так и международные правовые акты рекомендательного характера.

В 2001 году Российская Федерация выступила с инициативой разработки Конвенции о стандартах демократических выборов, избирательных прав и свобод в государствах - участниках СНГ (далее - Конвенции), подписанной 7 октября 2002 года в Кишиневе президентами Армении, Грузии, Кыргызстана, Молдовы, России, Таджикистана и Украины и вступившей в силу 11 ноября 2003 года ${ }^{1}$. Этот документ имеет обязательный характер для участников Конвенции. В Конвенции даны стандарты демократических выборов и механизмы их реализации, закреплены положения, связанные с финансированием и информационной поддержкой выборов, впервые конкретизирован правовой статус международных наблюдателей (статья 15). Следует согласиться с мнением специалистов (В.И. Лысенко, И.А. Евланов), что Конвенция, принятая по инициативе России, «является одним из подтверждений ее стремления к дальнейшей демократизации избирательного процесса, созданию единой международной системы гарантий избирательных прав и свобод участников выборов, обеспечению стабильности политического развития и развитию международных избирательных стандартов»².

Согласно статье 12 Конвенции запрещаются иностранные пожертвования кандидатам, политическим партиям, участвующим в выборах, общественным объединениям, которые находятся под влиянием кандидатов (политических партий) либо содействуют реализации их целей. Кандидаты, политические партии, участвующие в выборах, должны с установленной периодичностью представлять в избирательные органы и (или) иные органы, указанные в законе, сведения и отчеты о поступлении пожертвований в избирательные фонды, о вкладчиках соответствующих средств, а также о всех своих расходах из этих фондов на финансирование избирательной кампании.

В целях детализации положений данной Конвенции в рамках Содружества были приняты Рекомендации для международных наблюдателей СНГ по наблюдению за выборами и референдумами (новая редакция от 4 декабря 2004 года), Положение о миссии наблюдателей от СНГ на президентских и парламентских выборах, а также референдумах в государствах - участниках Содружества Независимых Государств (Решение Совета министров иностранных дел от 26 марта 2004 года, г. Минск),

${ }^{1}$ Грузия и Украина, хотя и подписали Конвенцию, до сих пор ее не ратифицировали и не стали ее полноценными участниками.

2 Международные избирательные стандарты. Сб. документов / Отв. ред. доктор юрид. наук В.И. Лысенко. М.: ЦИК России, 2009. С. 30. 
Декларация о принципах международного наблюдения за выборами и референдумами в государствах - участниках Содружества Независимых Государств (принята 25 ноября 2008 года).

Среди актов Содружества выделяется группа модельных законов в сфере противодействия коррупции (в том числе партийной и электоральной).

В соответствии с частью 1 статьи 8 Модельного закона «О противодействии коррупции» (принят на тридцать первом пленарном заседании Межпарламентской Ассамблеи государств - участников СНГ 25 ноября 2008 года), частью 1 статьи 5 Модельного закона «Основы законодательства об антикоррупционной политике» (принят на двадцать втором пленарном заседании Межпарламентской Ассамблеи государств участников СНГ 15 ноября 2003 года), реализация избирательных прав и деятельность политических партий относятся к числу приоритетных направлений правового регулирования в сфере противодействия коррупции.

Модельное законотворчество государств-участников СНГ в сфере противодействия коррупции является одной из форм правовой интеграции в формате Содружества. Согласно пунктам «в», «Г» статьи 4 Конвенции о Межпарламентской Ассамблеи государств-участников Содружества Независимых Государств от 26 мая 1995 г., статье 15 Регламента Межпарламентской Ассамблеи государств-участников Содружества Независимых Государств (принят 15 сентября 1992 г., дополнен 18 марта 1994 г.), пунктам 1.2 и 1.4 Положения о разработке модельных законодательных актов и Рекомендаций Межпарламентской Ассамблеи государств-участников Содружества Независимых Государств (принято МПА СНГ 14 апреля 2005 г., дополнено постановлением МПА СНГ 25 ноября 2008 г.) модельные законы являются международными правовыми актами рекомендательного характера. Они принимаются Межпарламентской Ассамблеей для ориентации согласованной законодательной деятельности и сближения законодательства государств-участников Содружества. По своей правовой природе и целям они отличаются от нормативных правовых актов, принимаемых национальными правотворческими органами государств СНГ. Если рассматривать в качестве цели нормативного правового акта нормативное регулирование общественных отношений, то целью модельного закона выступает правовое регулирование перспективных сфер интеграционного сотрудничества в рамках сближения законодательства государств Содружества ${ }^{1}$. Модельные акты предлагают возможность выбора государством модели правового регулирования общественных отношений с учетом национальных особенностей своей правовой системы ${ }^{2}$.

${ }^{1}$ Безбородов Ю.С. Международные модельные нормы. М., 2008; Безбородов Ю.С. Влияние международных модельных норм на внутригосударственные законодательные процедуры // Рос. юрид. журнал. 2011. № 3; Королев Ю.А. Процесс создания и уровень восприятия модельных законов Межпарламентской Ассамблеи СНГ // Журнал российского права. 2000. № 3. С. 135.

2 Следует согласиться с профессором Ю.А. Тихомировым, что «международные нормы влияют преимущественно на диспозицию национальных норм, а выбор 
Исходя из пункта 1.3. Положения о разработке модельных законодательных актов и рекомендаций Межпарламентской ассамблеи государств - участников Содружества Независимых Государств, к модельным законодательным актам Содружества относятся модельные кодексы и модельные законы СНГ. Как отмечено в данном Положении, отличия между ними заключаются в том, что:

1) модельный кодекс является результатом систематизации законодательства;

2) модельные кодексы регулируют однородные сферы общественных отношений, а модельные законы - конкретные виды (группы) общественных отношений в государствах Содружества.

В необходимых случаях модельные законодательные акты могут иметь форму типовых положений, уставов, соглашений.

Наличие ориентирующих норм, регулирующих финансирование избирательных кампаний на пространстве СНГ, крайне важно для борьбы государств-участников Содружества с партийной и электоральной коррупцией, легализацией денежных средств в условиях выборов, обеспечения целевого характера финансирования субъектов избирательного процесса и их публичной отчетности.

В Модельном законе СНГ «Основы законодательства об антикоррупционной политике» в качестве одной из задач антикоррупционной политики предусмотрено создание правового механизма, препятствующего подкупу граждан при проведении референдума и выборов в органы государственной власти и местного самоуправления.

Элементами подобного правового механизма являются установление ответственности за электоральные правонарушения и преступления, обладающие признаками коррупции, а также разработка антикоррупционных стандартов в сфере реализации избирательных прав и деятельности политических партий.

На основании части 4 статьи 8 Основ законодательства об антикоррупционной политике, к административным коррупционным правонарушениям электоральной направленности относятся следующие противоправные, виновные действия (бездействие), за которые предусмотрена административная ответственность: вмешательство в работу избирательной комиссии; подкуп избирателей или участников референдума; непредоставление или неопубликование отчета, сведений о поступлении и расходовании средств, выделенных на подготовку и проведение выборов, референдума; незаконное использование денежных средств кандидатом, зарегистрированным кандидатом, избирательным объединением, избирательным блоком, инициативной группой по

конкретных регуляторов остается за национальным законодателем». Тихомиров Ю.А. Международно-правовые акты: природа и способы влияния // Журнал российского права. 2002. № 1. 
проведению референдума ${ }^{1}$; использование незаконной материальной поддержки кандидатом, зарегистрированным кандидатом, избирательным объединением, избирательным блоком, инициативной группой по проведению референдума; финансирование избирательной кампании, проведения референдума помимо избирательных фондов, фондов для участия в референдуме и оказание иной запрещенной законом материальной поддержки; нецелевое использование бюджетных средств.

Перечень указанных в Основах законодательства составов административных правонарушений электоральной направленности представляется целесообразным дополнить за счет включения следующих противоправных деяний: «осуществление в период избирательной кампании рекламы и (или) благотворительной деятельности с нарушением законодательства о выборах и референдумах», «нарушение запрета на проведение в период избирательной кампании, кампании референдума лотерей и других основанных на риске игр, связанных с выборами и референдумами», «получение избирателем (участником референдума) выгоды материального и (или) нематериального характера за осуществление волеизъявления».

В соответствии с частью 5 статьи 8 к коррупционным преступлениям электоральной направленности в форме подкупа относятся воспрепятствование осуществлению избирательных прав или работе избирательных комиссий, запрещенные под угрозой наказания Уголовным кодексом, в случае совершения соответствующего деяния путем подкупа. На взгляд автора, эффективность законодательного противодействия коррупции в избирательном процессе можно было бы повысить путем введения в Основы законодательства об антикоррупционной политике уголовной ответственности за фальсификацию избирательных документов, документов референдума, связанную с подкупом.

Правовые запреты, сформулированные в диспозициях административно-правовых и уголовно-правовых норм, дополняются системой антикоррупционных стандартов в сфере реализации избирательных прав и деятельности политических партий.

Антикоррупционные стандарты представлены едиными гарантиями, ограничениями и запретами, обеспечивающими уменьшение воздействия коррупции на функционирование данной сферы.

Система антикоррупционных стандартов в сфере реализации избирательных прав и деятельности политических партий закреплена в статье 18 Основ законодательства об антикоррупционной политике.

В целях предупреждения коррупции в сфере реализации избирательных прав и деятельности партий при проведении выборов на

${ }^{1}$ В Российской Федерации в соответствии с Федеральным законом от 21 июля 2005 года № 93-Ф3 «О внесении изменений в законодательные акты Российской Федерации о выборах и референдумах и иные законодательные акты Российской Федерации» избирательные блоки исключены из числа субъектов избирательного процесса. 
должности органов государственной власти и местного самоуправления национальным законодательством устанавливаются:

1) гарантии на:

равное участие в составе избирательных комиссий представителей кандидатов на соответствующие должности с момента выдвижения таких кандидатов;

возврат в бюджет кандидатами, не избранными на соответствующие должности, денежных средств, выделенных на проведение избирательной кампании;

2) запретьл на:

предоставление кандидатами на соответствующие должности или от их имени в качестве подарков избирателям во время проведения избирательной кампании либо лицам, имеющим право на участие в референдуме, в период его проведения, имущества, прав на него, услуг или льгот имущественного характера;

использование кандидатами на должности органов государственной власти или местного самоуправления финансовой и иной поддержки юридических и физических лиц за исключением случаев, прямо предусмотренных законодательством;

использование в случаях и порядке, прямо предусмотренных законодательством, во время избирательной кампании кандидатами на соответствующие должности своего публичного статуса и связанных с ним возможностей для достижения целей избирательной кампании;

отнесение к конфиденциальной информации данных об имуществе, обязательствах имущественного характера, доходах и расходах кандидатов на замещение соответствующих должностей в органах государственной власти и местного самоуправления, их супругов и близких родственников ${ }^{1}$;

участие в составе комиссий референдума, а также в составе избирательных комиссий по выборам на соответствующие должности лиц, имеющих или когда-либо имевших судимость за коррупционные преступления, а также преступления, связанные с коррупционными, либо подвергавшихся административным или дисциплинарным взысканиям за совершение коррупционных правонарушений;

регистрацию в качестве кандидатов на соответствующие должности лиц, имеющих или когда-либо имевших судимость за коррупционные преступления, а также преступления, связанные с коррупционными.

Как мы видим, данная система антикоррупционных стандартов выстроена по модели «гарантии - запреты». Третий элемент

1 Статья 11 Модельного закона «О противодействии коррупции» к мерам противодействия коррупции относит декларирование доходов, расходов и имеющегося имущества депутатами законодательных (представительских) органов власти, органов местного самоуправления, зарегистрированными кандидатами в депутаты законодательных (представительских) органов власти, органов местного самоуправления, а также их близкими родственниками. 
антикоррупционных стандартов в сфере реализации избирательных прав и деятельности партий при проведении выборов - «ограничения» предусмотрен в Модельном законе «О противодействии коррупции».

Согласно статье 12 Модельного закона «О противодействии коррупции» для лиц, претендующих на занятие должностей депутатов законодательных (представительских) органов власти, органов местного самоуправления, а также лиц, занимающих указанные должности, могут устанавливаться определенные ограничения и запреты, связанные с выполнением ими своих служебных обязанностей. При этом они должны ставиться в известность о необходимости соблюдения этих ограничений и запретов, а также о мерах ответственности в случае их невыполнения. Непринятие ограничений является самостоятельным основанием для отказа в привлечении лица к выполнению соответствующих служебных функций, либо увольнения или освобождения от занимаемой должности.

Легальная конструкция антикоррупционных стандартов в сфере реализации избирательных прав и деятельности политических партий предполагает выделение двух фрагментов: а) стандартов, касающихся правового статуса субъектов избирательного процесса (в первую очередь, организаторов выборов и кандидатов); б) стандартов финансирования избирательной кампании.

В Модельном законе определены условия несовместимости статуса членов избирательных комиссий и зарегистрированных кандидатов. Лица, имеющие или когда-либо имевшие судимость за коррупционные преступления, а также за преступления, связанные с коррупционными, не могут быть членами избирательных комиссий и зарегистрированными кандидатами на выборные должности в органах государственной власти и органах местного самоуправления. Кандидаты не могут использовать свой публичный статус и связанные с ним возможности (т.н. «административный ресурс») для достижения целей избирательной кампании. Данная группа стандартов касается правового статуса субъектов избирательного процесса.

Вторая группа антикоррупционных стандартов связана с финансированием избирательной кампании. Сюда следует отнести: возврат неизбранными кандидатами бюджетных денежных средств, выделенных на проведение избирательной кампании; запрет на предоставление кандидатами или от их имени имущества, прав на него, услуг или льгот имущественного характера избирателям; запрет на использование кандидатами финансовой и иной поддержки юридических и физических лиц, прямо не предусмотренной законодательством; запрет на отнесение к конфиденциальной информации данных об имуществе, обязательствах имущественного характера, доходах и расходах кандидатов на замещение соответствующих должностей в органах государственной власти и местного самоуправления, их супругов и близких родственников.

Такая конструкция представляется усеченной и могла бы быть дополнена информационными антикоррупционными стандартами. К данной группе антикоррупционных стандартов могли бы быть отнесены: открытость 
и гласность в деятельности избирательных комиссий; опубликование в средствах массовой информации сведений и отчетов кандидатов (политических партий) о поступлении пожертвований в избирательные фонды, о вкладчиках соответствующих средств, а также о всех своих расходах из этих фондов на финансирование избирательной кампании.

Статья 9 Модельного закона «О противодействии коррупции» устанавливает широкий перечень субъектов, осуществляющих противодействие коррупции. Наряду с государственной системой противодействия коррупции, в которую входят правотворческие, контрольно-надзорные и правоохранительные органы (суды, органы прокуратуры, безопасности, внутренних дел (полиция)), уполномоченные на осуществление оперативно-розыскных мероприятий, производство дознания и предварительного (досудебного) следствия, в качестве субъектов противодействия коррупции законодатель выделяет органы местного самоуправления, политические партии и иные общественные объединения, а также отдельных граждан.

Часть 4 данной статьи определяет, что «отдельные физические лица участвуют в формировании и реализации противодействия коррупции через государственные органы, органы местного самоуправления, политические партии и иные общественные объединения, а также путем участия в выборах и/или референдуме» ${ }^{1}$.

Если с возможностью непосредственного участия политических партий в реализации мер противодействия партийной и электоральной коррупции еще можно согласиться (представление партиями отчетов о финансовой деятельности, исключение из партийных списков кандидатов, имеющих судимость за коррупционные преступления), то наделение граждан правами субъекта противодействия коррупции путем участия в выборах представляется надуманным. Как правило, основной целью участия граждан в выборах является выражение своих политических предпочтений (активное избирательное право), а также замещение выборной должности или депутатского мандата (пассивное избирательное право).

Элементом международно-правовых основ противодействия партийной и электоральной коррупции в формате СНГ являются акты Шанхайской организации сотрудничества (ШОС).

На основании пункта 10 Душанбинской Декларации ШОС от 28 августа 2008 года государства-члены ШОС обмениваются опытом по вопросам выполнения международных договоров по правам человека, поддерживают взаимодействие ШОС с другими региональными организациями и интеграционными объединениями по вопросам гуманитарного сотрудничества и поощрения прав человека.

${ }^{1}$ В статье 7 Основ законодательства об антикоррупционной политике в качестве непосредственной формы участия граждан в формировании и реализации антикоррупционной политики упоминается только референдум. 
В разделе IV Астанинской Декларации десятилетия ШОС от 15 июня 2011 года приоритетными направлениями в деятельности ШОС признаны укрепление и развитие связей с $\mathrm{OOH}$ в области борьбы с новыми вызовами и угрозами экономического, социального, гуманитарного и культурного развития. Создание благоприятных условий для торговли и инвестиций, контроль за финансовыми потоками предполагают, среди прочего, сотрудничество членов ШОС по линии противодействия коррупции.

Гуманитарное сотрудничество ШОС в политической сфере реализуется, главным образом, в рамках избирательного процесса. Соблюдение международных обязательств по наблюдению за выборами на территории государств - участников ШОС осуществляется на основе Положения о Миссии наблюдателей от Шанхайской организации сотрудничества на президентских и /или парламентских выборах, а также референдумах (утверждено решением Совета министров иностранных дел государствчленов ШОС от 15 мая 2006 г. № 8). Настоящее Положение определяет общие принципы и правила организации и осуществления ШОС международного наблюдения на выборах и референдумах ${ }^{1}$.

Рассмотрев систему международных актов в сфере противодействия партийной и электоральной коррупции, следует уделить внимание развитию международных антикоррупционных правовых основ в данной сфере.

Исходя из разработанности массива антикоррупционных международных актов и содержания правовых мер противодействия коррупции, можно выделить несколько основных этапов эволюции международно-правовых основ противодействия коррупции (в том числе, партийной и электоральной):

1. Конец 70-х гг. ХХ в. - начало 90-х гг. ХХ в.

2. Середина 90-Х гг. ХХ в. - конец 90-Х гг. ХХ в.

3. Начало XXI в. - н.в.

В рамках первого этапа (конец 70-х гг. ХX в. - начало 90-х гг. XX в.) Организацией Объединенных Наций были предприняты попытки сформулировать определение коррупции, а также закрепить общую позицию мирового сообщества и международных организаций по отношению к коррупционным деяниям.

На втором этапе (середина 90-х гг. ХX в. - конец 90-х гг. XX в.) Советом Европы была создана общеевропейская правовая система противодействия коррупции, установлены приоритетные сферы предупреждения коррупции, разработаны программы борьбы с коррупцией и учреждена специализированная антикоррупционная организация ГРЕКО. В Хартии европейской безопасности ОБСЕ были закреплены обязательства государств-участников вести борьбу с коррупцией во всех измерениях ОБСЕ.

Tретий этап (начало XXI в. - н.в.) связан с присоединением большинства государств СНГ к ГРЕКО, участием государств Содружества в

1 Международные избирательные стандарты. Сб. документов / Отв. ред. доктор юрид. наук В.И. Лысенко. М.: ЦИК России, 2009. С. 910-913. 
формировании международной антикоррупционной правовой базы и разработкой специализированных актов Совета Европы и СНГ по противодействию партийной и электоральной коррупции.

В этот период международные соглашения Совета Европы о противодействии коррупции были дополнены модельным кодексом поведения государственных служащих и специализированными рекомендациями о финансировании политических партий, об общих принципах борьбы с коррупцией при финансировании политических партий и избирательных кампаний. По инициативе Российской Федерации некоторыми государствами-участниками СНГ был подписан и ратифицирован первый юридически-обязывающий международный документ, закрепивший комплекс стандартов демократических выборов (в том числе вопросы финансирования выборов, избирательных кампаний политических партий и кандидатов) - Конвенция о стандартах демократических выборов, избирательных прав и свобод в государствах участниках СНГ. В результате модельного законотворчества Межпарламентской Ассамблеи государств-участников СНГ были приняты Основы законодательства об антикоррупционной политике и Модельный закон СНГ «О противодействии коррупции», содержащие антикоррупционные стандарты в сфере реализации избирательных прав и деятельности политических партий.

В качестве перспективных направлений эволюции международноправовых основ противодействия партийной и электоральной коррупции на пространстве Содружества Независимых Государств можно выделить: дальнейшую ратификацию конвенционных соглашений в сфере противодействия коррупции; международное регулирование порядка финансирования использования информационных технологий в избирательном процессе, регламентацию расходов на предвыборную агитацию в сети Интернет; совершенствование методики антикоррупционной экспертизы международных правовых актов, регулирующих деятельность политических партий и избирательный процесс; заключение соглашений о правовой помощи по уголовным и гражданским делам о коррупционных правонарушениях; правовое регулирование двусторонних и многосторонних антикоррупционных расследований; приведение законодательства государств - участников СНГ о выборах и политических партиях в соответствие с антикоррупционными стандартами модельных законов Межпарламентской Ассамблеи СНГ.

Красинский Владислав Вячеславович доктор юридических наук, член Общественного научно-методического Совета при ЦИК России 